\title{
Phosphate, Phosphide, Nitride and Carbide Capacity Predictions of Molten Melts by Using an Artificial Neural Network Approach
}

\author{
Bora DERIN, ${ }^{1) *}$ Emre $\mathrm{ALAN}^{2},{ }^{2)}$ Masanori SUZUKI ${ }^{3)}$ and Toshihiro TANAKA ${ }^{3)}$ \\ 1) Metallurgical and Materials Eng. Dept., Istanbul Technical University, Maslak, Istanbul, 34469 Turkey. \\ 2) Steelmaking and Casting Tech. R\&D Dept., Eregli Iron and Steel Works, Co. (ERDEMIR), Zonguldak, 67330 Turkey. \\ 3) Division of Materials and Manufacturing Science, Osaka University, 2-1 Yamadaoka, Suita, Osaka, 565-0871 Japan.
}

(Received on May 5, 2015; accepted on November 16, 2015)

\begin{abstract}
In the present study, the impurity capacities (Ci) of phosphate, phosphide, nitride and carbide in binary and multi-component molten melt systems at different temperatures were estimated using the artificial neural network approach. The experimental data taken from the previous studies were introduced to the artificial neural network, then the calculated results were plotted against the experimental values for comparative purposes. Besides, iso-phosphate capacity contours on the liquid region of $\mathrm{CaO}-\mathrm{CaF}_{2}-\mathrm{Al}_{2} \mathrm{O}_{3}$ ternary phase diagram at $1773 \mathrm{~K}$ were generated and plotted by using the neural network model results. The calculated results obtained through neural network computation agreed well with the experimental ones and were found more accurate than those estimates based on some models.
\end{abstract}

KEY WORDS: impurity capacities; phosphate; phosphide; nitrogen; carbide; molten melts; artificial neural network.

\section{Introduction}

Analogous to sulfur, the impurities such as phosphorus, nitrogen and carbon should also be kept under control during steelmaking process due to their possible adverse effects on the steel quality. For some decades, impurity capacity $\left(\mathrm{C}_{\mathrm{i}}\right)$ modeling has been attracted considerable attention by researchers, since it has a potential use for predicting the ability of slag for removing the impurities in hot metal. A number of empirical, semi-empirical and/or theoretical models have been developed to estimate the capacities of phosphorus, nitrogen and carbon in molten melts. ${ }^{1-10)}$ For example, Selin et al. developed a model for the calculations of phosphate capacities $\left(\mathrm{C}_{\mathrm{PO}_{4}^{3-}}\right)$ using temperature and basicity index for $\mathrm{CaO}-\mathrm{SiO}_{2}-\mathrm{CaF}_{2}$ slags. ${ }^{2}$ Koyabashi et al. presented a simple linear formula for phosphate capacity predictions as functions of temperature for the slag composition of $\mathrm{X}_{\mathrm{MnO}} / \mathrm{X}_{\mathrm{SiO} 2}=2.5$ for the $\mathrm{MnO}-\mathrm{SiO}_{2}-\mathrm{Fe}_{\mathrm{t}} \mathrm{O}$ system and $\left(\mathrm{X}_{\mathrm{MnO}}+\mathrm{X}_{\mathrm{MgO}}\right) / \mathrm{X}_{\mathrm{SiO} 2}=2.5$ for the $\mathrm{MnO}-\mathrm{SiO}_{2}-\mathrm{Fe}_{t} \mathrm{O}-$ $\mathrm{MgO}_{\text {satd }}$ systems. ${ }^{3)}$ Mori used the optical basicity concept in their formula for $\mathrm{CaO}-\mathrm{MgO}-\mathrm{SiO}_{2}-\mathrm{Fe}_{\mathrm{t}} \mathrm{O}$ slags at $1873 \mathrm{~K}$. Kobayashi and Kodama enhanced a temperature-dependent formula for phosphate capacity prediction using the same concept for $\mathrm{MnO}-\mathrm{Fe}_{\mathrm{t}} \mathrm{O}-\mathrm{CaO}-\mathrm{MgO}-\mathrm{SiO}_{2}$ slags. ${ }^{5)}$ Apart from above mentioned models, Yang et al. developed a thermodynamic model for predicting the phosphate capacity of $\mathrm{CaO}-\mathrm{SiO}_{2}-\mathrm{MgO}-\mathrm{FeO}-\mathrm{Fe}_{2} \mathrm{O}_{3}-\mathrm{MnO}-\mathrm{Al}_{2} \mathrm{O}_{3}-\mathrm{P}_{2} \mathrm{O}_{5}$ convertor slags based on the ion and molecule coexistence theory (IMCT). ${ }^{6}$ Maramba and Eric investigated the phosphide

\footnotetext{
* Corresponding author: E-mail: bderin@itu.edu.tr

DOI: http://dx.doi.org/10.2355/isijinternational.ISIJINT-2015-236
}

capacity $\left(C_{P^{3-}}\right)$ of ferromanganese smelting slags under highly reducing conditions. ${ }^{7)}$ They created the quadratic regression models with variable molar ratio of oxides which define the relationship between the phosphide capacities of ferromanganese slags and the slag constituents under $\mathrm{CO}$ and $\mathrm{Ar}-\mathrm{CO}$ atmospheres at $1773 \mathrm{~K}$. Sasabe et al. investigated the nitride capacities $\left(C_{N^{3-}}\right)$ of molten $\mathrm{CaO}-\mathrm{SiO}_{2}-$ $\mathrm{Al}_{2} \mathrm{O}_{3}$ slags containing $\mathrm{TiO}_{2}$ or $\mathrm{ZrO}_{2}$ at the temperatures between 1710 and $1905 \mathrm{~K}$ and they made a temperature depended simple regression model. ${ }^{8)}$ Shin and Lee studied on the nitrogen solubility of $\mathrm{CaO}-\mathrm{Al}_{2} \mathrm{O}_{3}-\mathrm{CaF}_{2}$ melts and developed a formula based on the optical basicity concept for $1773 \mathrm{~K}^{9)}$ Park and Min investigated the carbide capacities of $\mathrm{CaO}-\mathrm{SiO}_{2}-\mathrm{CaF}_{2}\left(-\mathrm{Na}_{2} \mathrm{O}\right)$ slags at $1773 \mathrm{~K}$ and they presented a linear regression formula which express the relationship between the carbide capacity $\left(C_{C_{2}^{2-}}\right)$ and the activity of $\mathrm{CaO}$ in both slags. ${ }^{10)}$

Most of the models mentioned above are in agreement with experimental results only within a certain composition and/or temperature range. In many cases, it is not possible to produce reliable data far from the experimental zone, such as for predicting capacity iso-contours in complex systems due to either lack of thermodynamic data or consequence of the inadequacy of the regression model. In the present study, an advanced empirical approach, neural network computation will be described briefly and applied for the estimation of impurity capacities of phosphate, phosphide, nitride and carbide in binary and multicomponent slags and flux systems which consist of $\mathrm{CaO}, \mathrm{SiO}_{2}, \mathrm{Al}_{2} \mathrm{O}_{3}, \mathrm{Fe}_{\mathrm{t}} \mathrm{O}, \mathrm{MgO}, \mathrm{MnO}$, $\mathrm{Na}_{2} \mathrm{O}, \mathrm{BaO}, \mathrm{Cr}_{2} \mathrm{O}_{3}, \mathrm{TiO}_{2}, \mathrm{Li}_{2} \mathrm{O}, \mathrm{B}_{2} \mathrm{O}_{3}, \mathrm{CaF}_{2}, \mathrm{~K}_{2} \mathrm{O}$ and $\mathrm{ZrO}_{2}$ at different temperatures. 


\section{Neural Network Computation for $C_{i}$ Calculations}

Artificial Neural Network (ANN) computation is a processing method which mimics the features of the human brain. ${ }^{11-13)}$ The human brain contains approximately 100 billion nerve cells (neurons) and each neuron is a functioning unit of the nervous system consisting of dendrite, soma, axon and synapse (Fig. 1(a)). In artificial equivalent of a biological neuron (Fig. 1(b)), communication is done via input signals. A neuron accepts inputs associated with different weights (single number) from multiple neurons.

The summation of the inputs (intensity) is multiplied by their associated weight. When the intensity of the signal is high enough to pass over a certain critical value (threshold), then an output signal (conventionally "1") is transmitted through axon and synapse to the next neuron, otherwise it outputs zero. The state that the intensity of signal exceeds the threshold is called "ignition" and it is stated in a sigmoid function shown in Eq. (1) in the neural network concept.

$$
y=f(x)=1 /[1+\exp (-\eta \cdot x)]
$$

where, $x$ is an input value and $y$ is the output. $\eta$ is a coefficient which regulates the shape of the sigmoid curve. Figure 2 shows a schematic diagram of the back propagation method in a three layers-type neural network computation which contains an input layer, a middle (hidden) layer and an output layer.

ANN is an important sub-branch of the artificial intelligence that is mostly used for solving classification and prediction problems. The main advantage of the neural network is its ability to learn. So it adapts itself to how to do tasks based on the data given for training or initial experience, meaning it can change its internal structure based on the information flowing through it. ANN approach has become very common in many disciplines. In the metallurgy field, some studies exist on the estimation of impurity capacities and physical properties of molten slags by artificial neural network approach in the literature. Derin et al. predicted sulphide capacities $\left(\mathrm{C}_{\mathrm{S}}{ }^{2-}\right)$ in some binary and multi-component melts at different temperatures, and also generated iso-sulfide capacity contours on liquid regions of some ternary melt phase diagrams. ${ }^{1)}$ Tanaka et al. predicted viscosity and solidification temperature of mold fluxes in multi-component systems using neural network computing. ${ }^{14,15)}$ Nakamoto et al. applied this approach to estimate the surface tension in ternary silicate melts. ${ }^{16)}$ Both studies also discussed on the criteria for designing the number of units in the middle layer in order to obtain optimum results.

In the present study, the computation was carried out by using SlagVis software. The SlagVis was designed by Research Center of Computational Mechanics Inc., Osaka University, and Sumitomo Metal Industries Ltd. to estimate first the physical properties of multi-component slags by neural network model. ${ }^{1,14-16)}$ Since the calculation method is the same as that for those physical properties, the program was also found applicable for the $\mathrm{Ci}$ predictions. The following initial values were selected in the software for all calculations; number of middle unit 5 , maximum iteration 1000000 , learning rate 1.5 which is a constant used in artificial neural network learning algorithms to affect the speed of learning, and target relative error 0.02. These values,

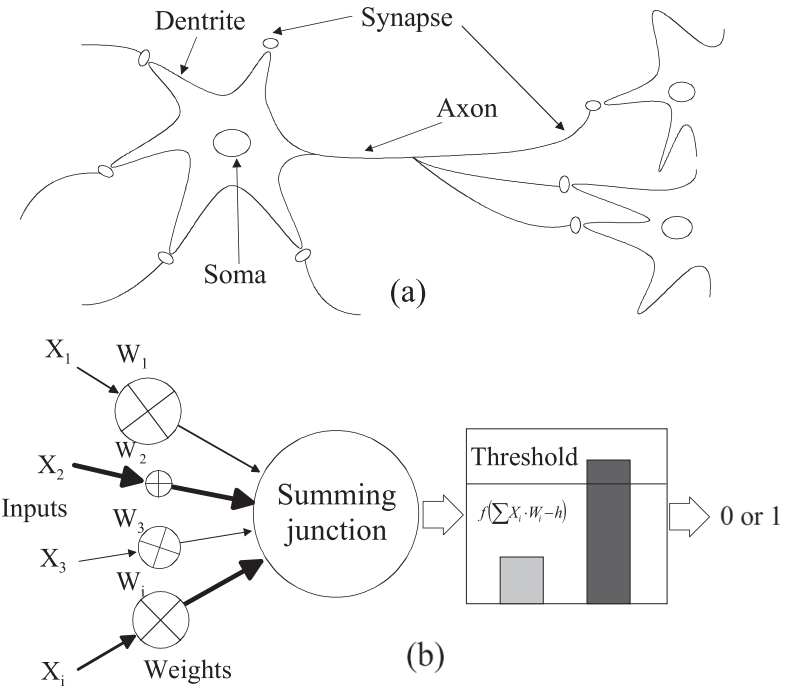

Fig. 1. Schematic diagrams of (a) a biological neuron and (b) a simple artificial neuron.

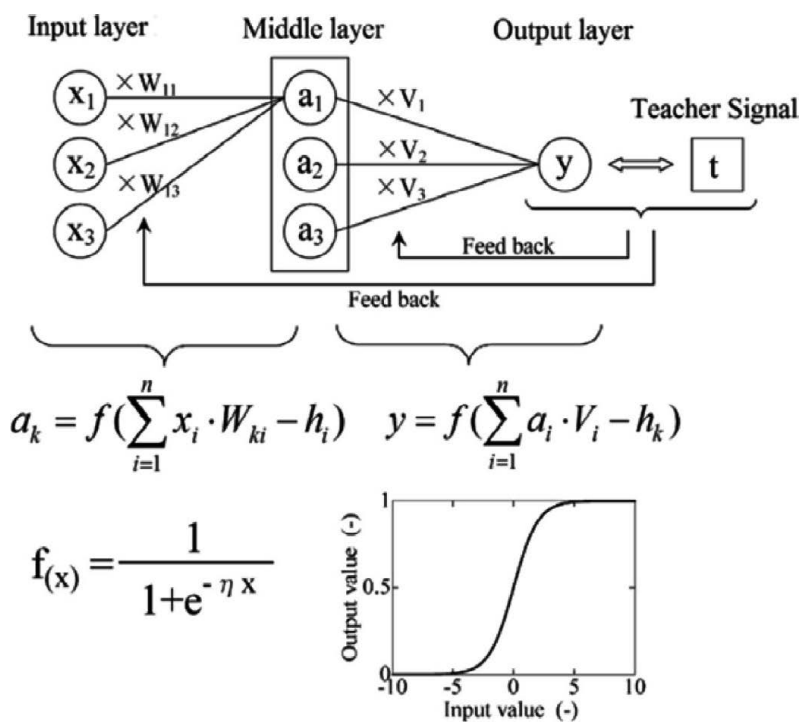

Fig. 2. Schematic diagram of the back-propagation approach in 3 layers-type neural network structure with 3 units in the input layer and 3 units in the middle layer.

which were selected as the optimal parameters for the present study, were obtained by trial and error until an adequate match was achieved between experimental and calculated $\mathrm{Ci}$ values. In calculations, input values were mass percent of the components, whereas the experimental $\mathrm{Ci}$ results in logarithmic scale were served as teaching values that provide feedback. Then, the impurity capacity predictions of molten slags were calculated using this network.

\section{Results and Discussions}

Since the artificial neural network model is based on an empirical approach, the consistency of the experimentally determined impurity capacity values to be used as teaching values in the model is very essential. The main difficulties in the present study were the lack of experimental data and/ or inconsistent $\mathrm{Ci}$ values of some similar slag compositions carried out by different authors. 
First comparison was made with experimental data, SlagVis and an empirical model developed with Statistical Analysis Software (SAS) for the prediction of phosphide capacity $\left(C_{P^{3-}}\right)$ of ferromanganese smelting slags under highly reducing atmosphere at $1773 \mathrm{~K}$. ${ }^{7)}$ Their quadratic regression model which define the relationship between the phosphide capacities of $\mathrm{FeO}-\mathrm{MgO}-\mathrm{MnO}-\mathrm{CaO}-\mathrm{SiO}_{2}-$ $\mathrm{Al}_{2} \mathrm{O}_{3}$ multicomponent slags and their compositions under $\mathrm{CO}$ atmosphere (partial pressure of oxygen $=1.22 \cdot 10^{-16}$ atm) was used in the present study. Figure 3 shows that SAS model gives improved results at higher phosphide capacity values, but its reliability decreases with decreasing the capacity values. However, the Neural Network model gives better results and thus, much lower "Root Mean Square Error" (RMSE $=0.0213)$ than the SAS model (RMSE $=0.1748)$.

Second comparison was made between experimental and calculated phosphate capacity $\left(C_{P_{O_{-}^{3-}}}\right)$ values obtained by ANN model and the ion and molecule coexistence theory (IMCT) for $\mathrm{CaO}-\mathrm{SiO}_{2}-\mathrm{MgO}-\mathrm{FeO}-\mathrm{Fe}_{2} \mathrm{O}_{3}-\mathrm{MnO}-\mathrm{Al}_{2} \mathrm{O}_{3}-$ $\mathrm{P}_{2} \mathrm{O}_{5}$ slags with 27 different composition and temperature (1 929-1 $986 \mathrm{~K})$ at the steelmaking endpoint during an 80-ton top-bottom combined blown converter. ${ }^{6}$ ) As can be seen in Fig. 4, IMCT model is in good agreement but slightly shifted in comparison with experimental results. Thus, Neural Network yields significantly lower RMSE values $(0.0190)$ compared to thermodynamic model based on IMCT $(0.1251)$.

The third comparison is selected between the experimental and calculated nitride capacity $\left(C_{N^{3-}}\right)$ values obtained by optical basicity and ANN model results for synthetically produced $\mathrm{CaO}-\mathrm{Al}_{2} \mathrm{O}_{3}-\mathrm{CaF}_{2}$ Melts at $1773 \mathrm{~K}$. ${ }^{9)}$ Figure 5 depicts that data points obtained by optical basicity method $($ RMSE $=0.1889)$ are widely scattered around the regression line. Thus, better results can be obtained with neural network approach $(\mathrm{RMSE}=0.0491)$ compared to optical basicity model.

Final comparison was made between experimental and calculated carbide capacity $\left(C_{C_{2}^{2-}}\right)$ values obtained by activity dependent regression model and SlagVis results for

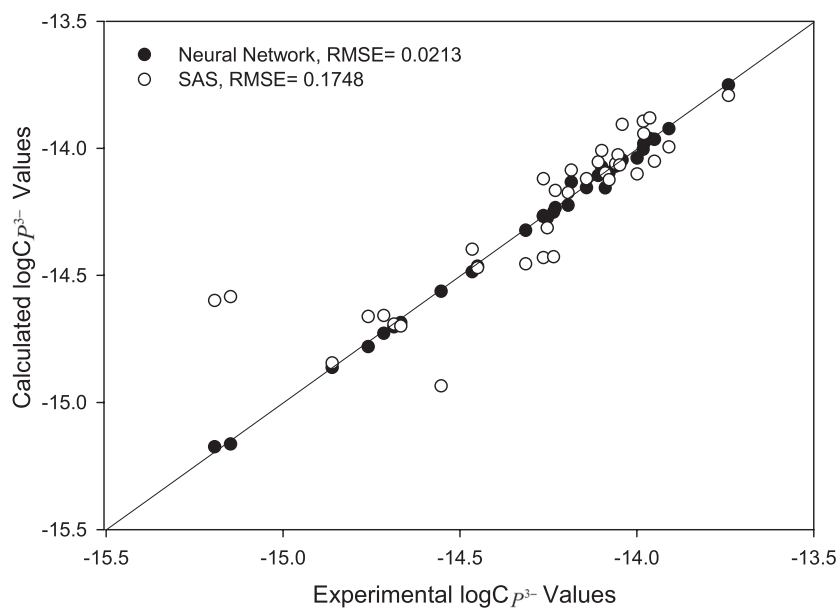

Fig. 3. Comparison between experimental and calculated phosphate capacity phosphide capacity $\left(C_{P^{3-}}\right)$ values obtained by SAS model and neural network computation for ferromanganese smelting slags.

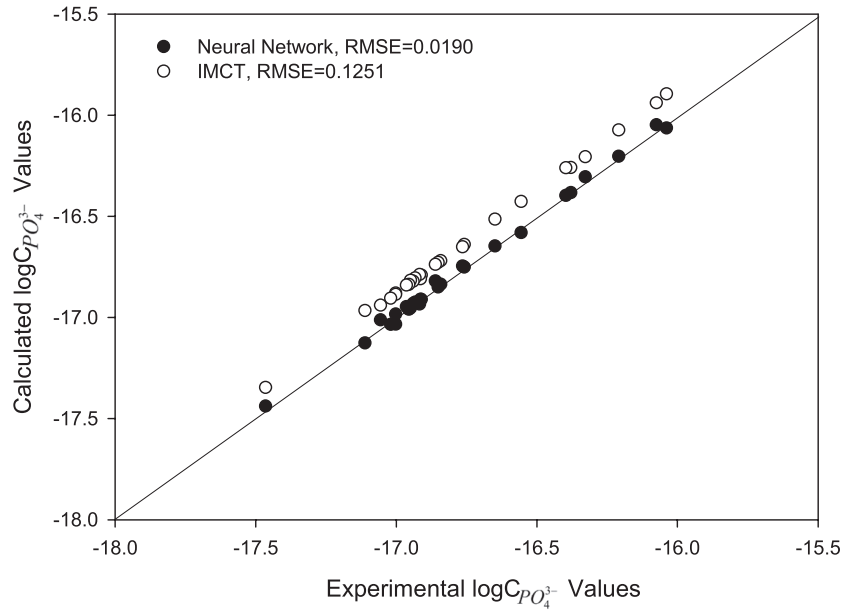

Fig. 4. Comparison between experimental and calculated phosphate capacity $\left(C_{\mathrm{PO}_{4}^{3-}}\right)$ values obtained by IMCT model and neural network computation for $\mathrm{CaO}-\mathrm{SiO}_{2}-\mathrm{MgO}-\mathrm{FeO}-$ $\mathrm{Fe}_{2} \mathrm{O}_{3}-\mathrm{MnO}-\mathrm{Al}_{2} \mathrm{O}_{3}-\mathrm{P}_{2} \mathrm{O}_{5}$ slags.

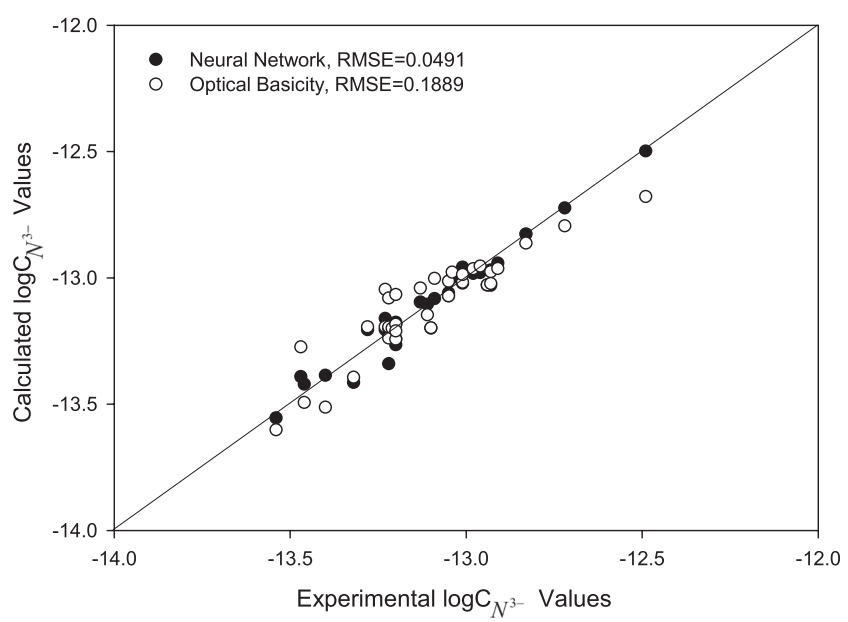

Fig. 5. Comparison between experimental and calculated nitride capacity $\left(C_{N^{3-}}\right)$ values obtained by optical basicity model and neural network computation for $\mathrm{CaO}-\mathrm{Al}_{2} \mathrm{O}_{3}-\mathrm{CaF}_{2}$ Melts at $1773 \mathrm{~K}$.

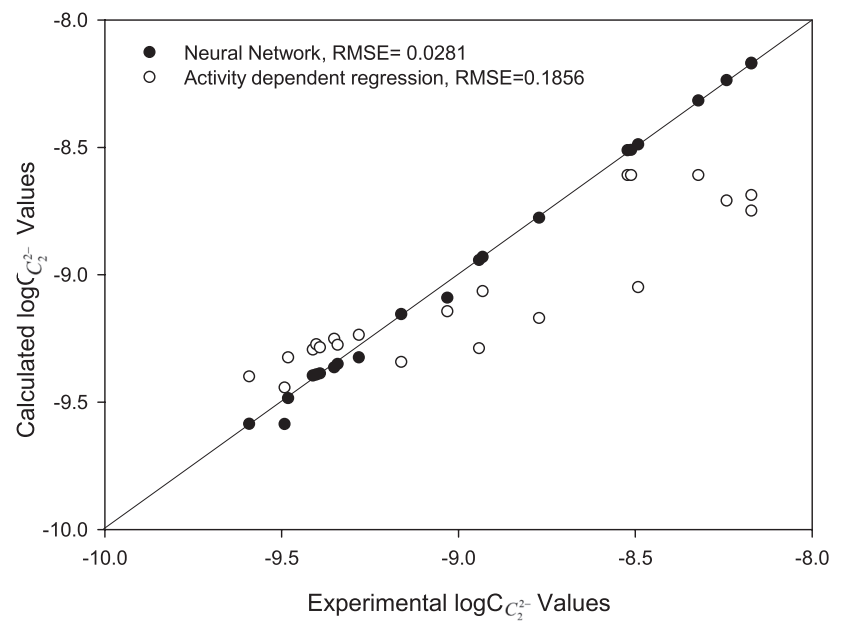

Fig. 6. Comparison between experimental and calculated carbide capacity $\left(C_{C_{2}^{2}}\right)$ values obtained by activity dependent regression model and neural network computation for $\mathrm{CaO}-\mathrm{CaF}_{2}-\mathrm{SiO}_{2}$ Melts at $1773 \mathrm{~K}$. 
$\mathrm{CaO}-\mathrm{CaF}_{2}-\mathrm{SiO}_{2}$ Melts at $1773 \mathrm{~K}^{10)} \mathrm{CaO}$ activity values of the ternary melts required for the regression model was calculated by using Equilibrium module of FactSage $6.4^{17}$ ) with FToxid and FactPS databases. As can be seen in Fig. 6, Neural Network approach $(\mathrm{RMSE}=0.0281)$ gives much closer match to the experimental data than the activity depended regression model $(\mathrm{RMSE}=0.1856)$.

The experimental data collected from the literature was used for the present neural network estimations of phosphate, phosphide, nitride and carbide capacities of binary and multi-component melts at different temperatures and listed in Table 1.

Figures 7 and 8 represent the comparison between experimental and calculated phosphate capacity $\left(C_{P_{0}-}\right)$ values of multicomponent silicate melts and halide containing multi-component oxide melts, respectively. Figures 9 and 10 show experimental nitride capacity $\left(C_{N^{3-}}\right)$ and carbide capacity $\left(C_{C_{2}^{2-}}\right)$ values against ANN calculated values, respectively. As seen in figures, very good compliance between artificial neural network predicted values and the experimental data points were found. This situation makes

Table 1. Experimental data used for the Neural Network $C_{i}$ estimation.

\begin{tabular}{|c|c|c|}
\hline Slag System & Temperature, $\mathrm{K}$ & Ref. \\
\hline $\mathrm{CaO}-\mathrm{BaO}-\mathrm{SiO}_{2}-\mathrm{FeO}$ & 1873 & 18) \\
\hline $\mathrm{MgO}-\mathrm{Na}_{2} \mathrm{O}-\mathrm{Fe}_{\mathrm{t}} \mathrm{O}-\mathrm{SiO}_{2}-\mathrm{P}_{2} \mathrm{O}_{5}$ & 1873 & 19) \\
\hline $\mathrm{CaO}-\mathrm{Fe}_{2} \mathrm{O}_{3}-\mathrm{FeO}-\mathrm{SiO}_{2}$ & 1573 & 20) \\
\hline $\mathrm{CaO}-\mathrm{SiO}_{2}-\mathrm{Na}_{2} \mathrm{O}$ & 1623 & 21) \\
\hline $\mathrm{CaO}-\mathrm{Fe}_{\mathrm{t}} \mathrm{O}-\mathrm{MgO}-\mathrm{B}_{2} \mathrm{O}_{3}-\mathrm{SiO}_{2}-\mathrm{P}_{2} \mathrm{O}_{5}$ & 1873 & 22) \\
\hline $\mathrm{MgO}-\mathrm{CaO}-\mathrm{SiO}_{2}-\mathrm{Fe}_{\mathrm{t}} \mathrm{O}-\mathrm{Al}_{2} \mathrm{O}_{3}-\mathrm{Na}_{2} \mathrm{O}$ & 1823,1873 & 23) \\
\hline $\mathrm{CaO}-\mathrm{Fe}_{\mathrm{t}} \mathrm{O}-\mathrm{MgO}-\mathrm{SiO}_{2}$ & 1813,1967 & 24) \\
\hline $\mathrm{CaO}-\mathrm{CaF}_{2}-\mathrm{Al}_{2} \mathrm{O}_{3}-\mathrm{BaO}$ & 1673 & 25) \\
\hline $\mathrm{CaO}-\mathrm{CaF}_{2}-\mathrm{Al}_{2} \mathrm{O}_{3}-\mathrm{Li}_{2} \mathrm{O}$ & 1573 & 25) \\
\hline $\mathrm{CaO}-\mathrm{CaF}_{2}-\mathrm{Al}_{2} \mathrm{O}_{3}-\mathrm{Na}_{2} \mathrm{O}$ & 1573 & 25) \\
\hline $\mathrm{CaO}-\mathrm{CaF}_{2}-\mathrm{BaF}_{2}-\mathrm{BaO}-\mathrm{MnO}$ & 1573 & 26) \\
\hline $\mathrm{CaO}-\mathrm{CaF}_{2}$ & $1773-1873$ & 27-29) \\
\hline $\mathrm{CaO}-\mathrm{CaF}_{2}-\mathrm{Cr}_{2} \mathrm{O}_{3}$ & $1773-1823$ & 27) \\
\hline $\mathrm{CaO}-\mathrm{FeO}-\mathrm{CaF}_{2}-\mathrm{SiO}_{2}$ & 1573 & 30) \\
\hline $\mathrm{CaO}-\mathrm{CaF}_{2}-\mathrm{SiO}_{2}-\mathrm{K}_{2} \mathrm{O}$ & $1473,1523,1573$ & 31) \\
\hline $\mathrm{CaO}-\mathrm{CaF}_{2}-\mathrm{SiO}_{2}-\mathrm{Na}_{2} \mathrm{O}$ & 1623 & 21) \\
\hline $\mathrm{CaO}-\mathrm{Al}_{2} \mathrm{O}_{3}$ & $1723-1923$ & $29,32-34)$ \\
\hline $\mathrm{CaO}-\mathrm{Al}_{2} \mathrm{O}_{3}-\mathrm{MgO}$ & 1873 & 34) \\
\hline $\mathrm{CaO}-\mathrm{Al}_{2} \mathrm{O}_{3}-\mathrm{Zr}_{2} \mathrm{O}_{3}$ & 1873 & 34) \\
\hline $\mathrm{CaO}-\mathrm{SiO}_{2}-\mathrm{TiO}_{x}$ & 1873 & 34) \\
\hline $\mathrm{CaO}-\mathrm{Al}_{2} \mathrm{O}_{3}-\mathrm{CaF}_{2}$ & 1773 & $9,25,35)$ \\
\hline $\mathrm{CaO}-\mathrm{SiO}_{2}-\mathrm{Al}_{2} \mathrm{O}_{3}$ & $1746-1841$ & 8) \\
\hline $\mathrm{CaO}-\mathrm{SiO}_{2}-\mathrm{Al}_{2} \mathrm{O}_{3}-\mathrm{TiO}_{2}$ & $1723-1793$ & 8) \\
\hline $\mathrm{CaO}-\mathrm{SiO}_{2}-\mathrm{Al}_{2} \mathrm{O}_{3}-\mathrm{ZrO}_{2}$ & $1710-1905$ & 8) \\
\hline $\mathrm{CaO}-\mathrm{CaF}_{2}-\mathrm{SiO}_{2}$ & 1773 & 10) \\
\hline $\mathrm{CaO}-\mathrm{CaF}_{2}-\mathrm{SiO}_{2}-\mathrm{Na}_{2} \mathrm{O}$ & 1773 & 10) \\
\hline $\mathrm{CaO}-\mathrm{SiO}_{2}-\mathrm{MnO}$ & 1773 & 36) \\
\hline
\end{tabular}

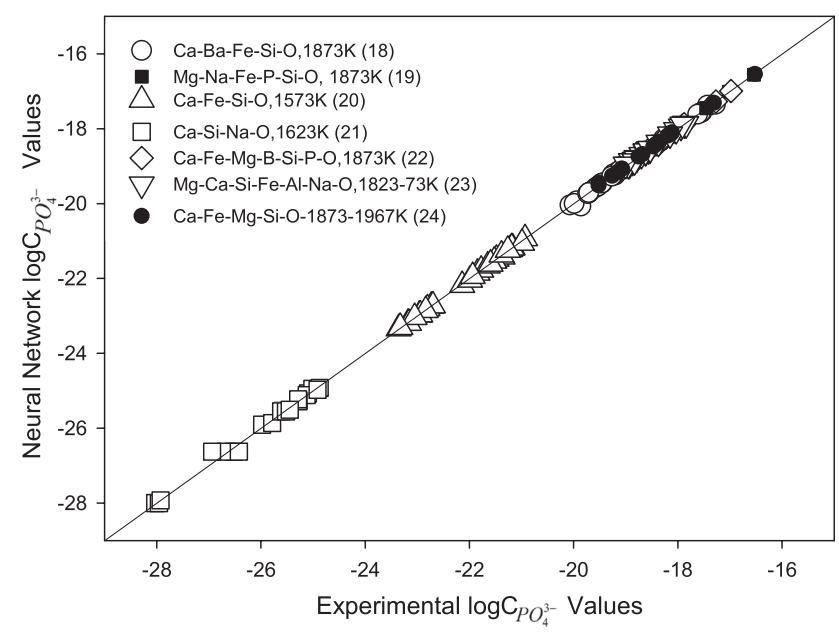

Fig. 7. Comparisons between experimental and calculated phosphate capacity $\left(\mathrm{C}_{\mathrm{PO}_{4}^{3-}}\right)$ values obtained by neural network computation for multicomponent silicate melts at different temperatures.

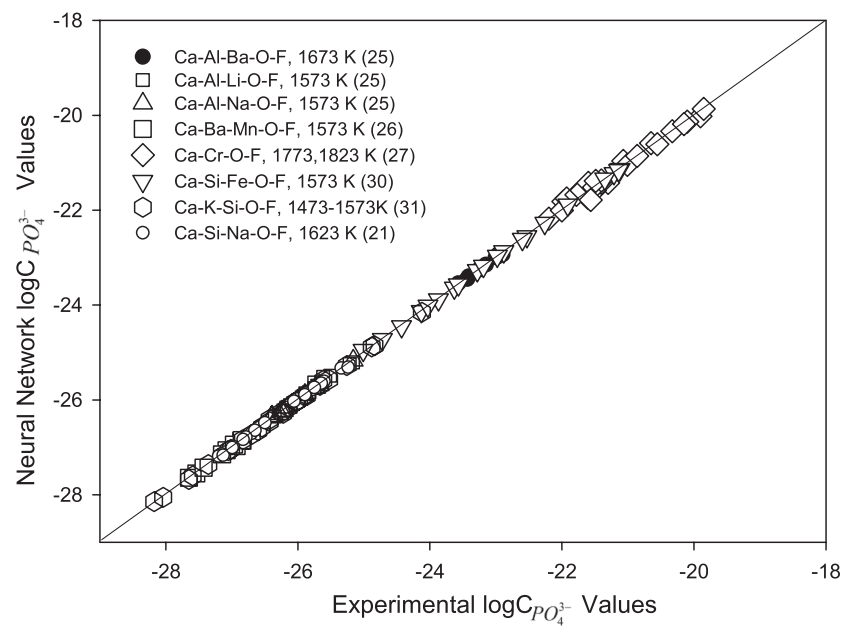

Fig. 8. Comparisons between experimental and calculated phosphate capacity values $\left(\mathrm{C}_{\mathrm{PO}_{4}^{3-}}\right)$ obtained by neural network computation for multicomponent halite melts at different temperatures.

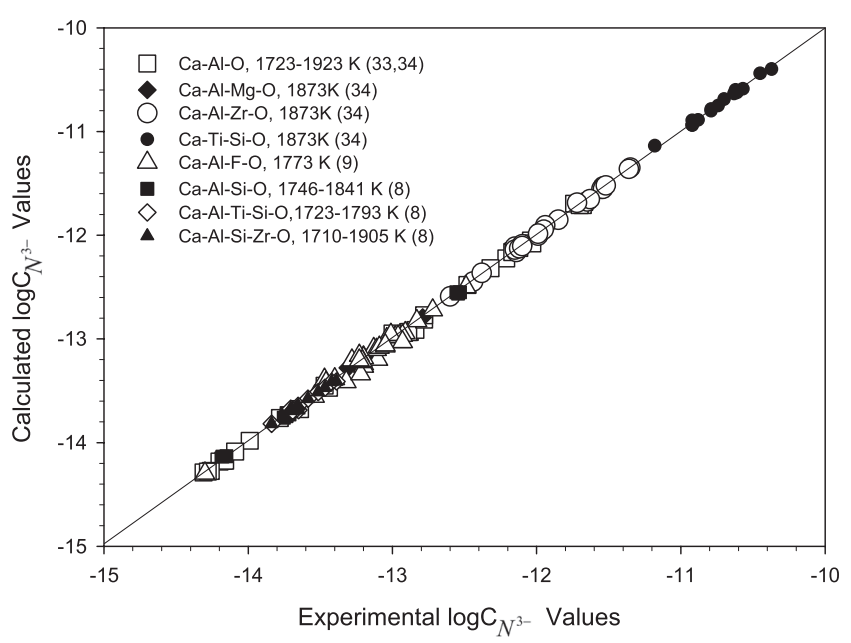

Fig. 9. Comparisons between experimental and calculated nitride capacity $\left(C_{N^{3-}}\right)$ values obtained by neural network computation for multicomponent melts at different temperatures. 
the AAN approach a good engineering tool to estimate reliable results.

Iso-phosphate capacity contours for different compositions of $\mathrm{CaO}-\mathrm{CaF}_{2}-\mathrm{Al}_{2} \mathrm{O}_{3}$ slag system at $1773 \mathrm{~K}$ were generated using the neural network model. Some experimental $C_{P_{4}^{3-}}$ values in Table 2, not only ternary but also of lower sub-systems neighbor to liquidus region were taken

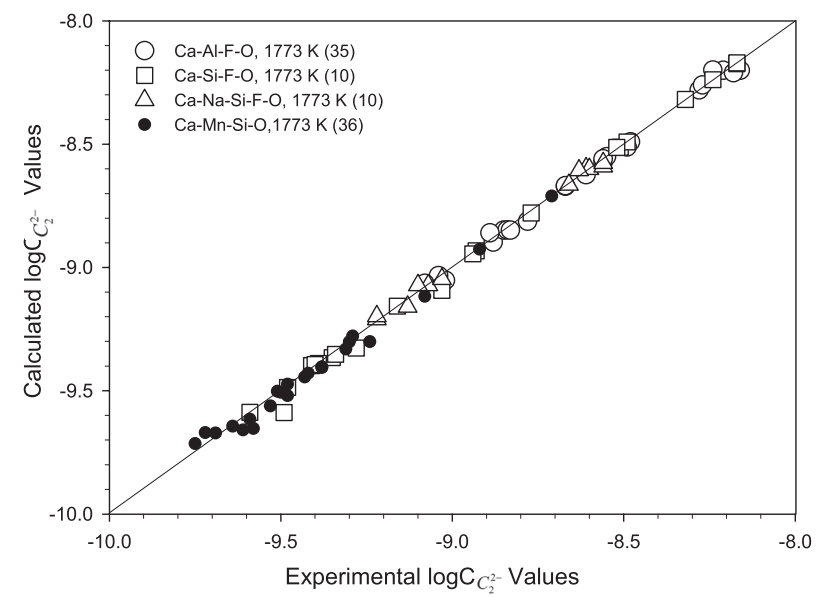

Fig. 10. Comparisons between experimental and calculated carbide capacity $\left(C_{C_{2}^{2}}\right)$ values obtained by neural network computation for multicomponent melts at different temperatures.

Table 2. Experimental data used for $\mathrm{NN}$ calculated iso-phosphate capacity contours for $\mathrm{CaO}-\mathrm{CaF}_{2}-\mathrm{Al}_{2} \mathrm{O}_{3}$ melts at $1773 \mathrm{~K}$.

\begin{tabular}{cc}
\hline Slag System & Ref. \\
\hline $\mathrm{CaO}-\mathrm{CaF}_{2}-\mathrm{Al}_{2} \mathrm{O}_{3}$ & $25)$ \\
$\mathrm{CaO}-\mathrm{CaF}_{2}$ & $27-29)$ \\
$\mathrm{CaO}-\mathrm{Al}_{2} \mathrm{O}_{3}$ & $29,32)$ \\
\hline
\end{tabular}

into account for each calculation. The experimental $C_{P O_{4}^{3-}}$ values of the melt compositions which are not in liquid region were neglected to prevent erroneous $C_{P O^{3-}}$ results. The iso-phosphate capacity contours were inserted to phase diagrams which were generated by FactSage 6.4 using "Phase Diagram" module. ${ }^{17)}$

In the calculations, the number of parameters strongly depends on the component number of the slag. Temperature is also included to the input set when experimental $\mathrm{Ci}$ results obtained at different temperature are added to the calculations. For example, in order to calculate the $\mathrm{Ci}$ of a threecomponent slag system at a certain temperature, if the num-

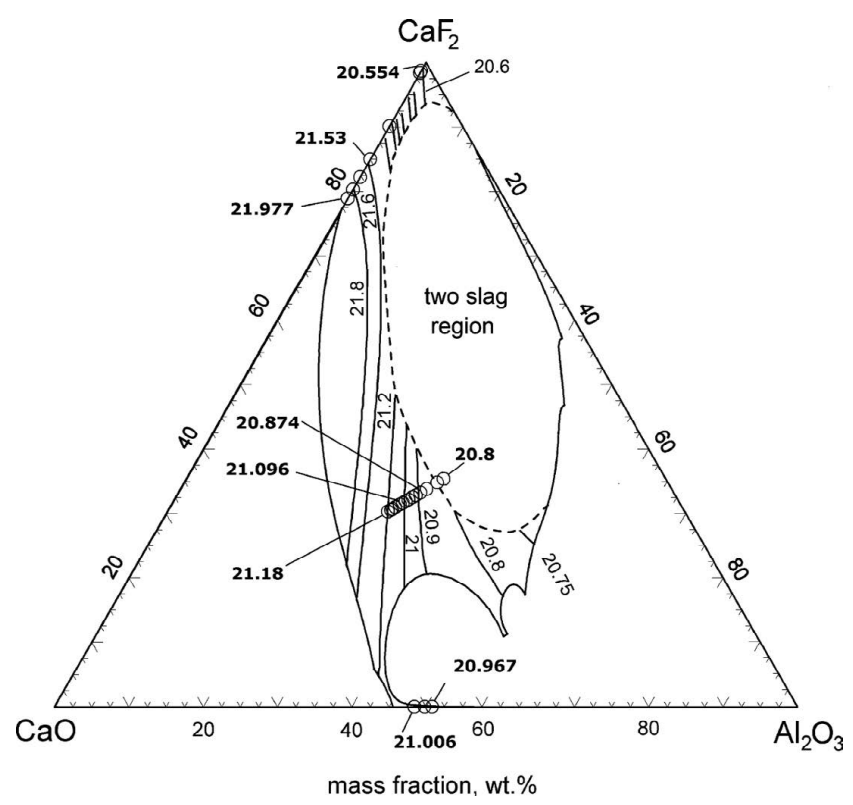

Fig. 11. Artificial neural network predicted iso-phosphate capacity contours in liquid region of $\mathrm{CaO}-\mathrm{CaF}_{2}-\mathrm{Al}_{2} \mathrm{O}_{3}$ melts at $1773 \mathrm{~K}$.

Table 3. List of parameter values for $\mathrm{CaO}-\mathrm{CaF}_{2}-\mathrm{Al}_{2} \mathrm{O}_{3}$ slag system at $1773 \mathrm{~K}$ indicated in Fig. 11.

\begin{tabular}{|c|c|c|c|c|c|}
\hline \multicolumn{6}{|c|}{$\begin{array}{l}\text { Number of Input Unit } \\
3\end{array}$} \\
\hline \multicolumn{6}{|c|}{$\begin{array}{l}\text { Number of Middle Unit } \\
5\end{array}$} \\
\hline \multicolumn{6}{|c|}{ Weight Matrix of INPUT to MIDDLE layer } \\
\hline Components & No. 1 & No. 2 & No. 3 & No. 4 & No. 5 \\
\hline $\mathrm{Wt} \% \mathrm{CaO}$ & -5.735677 & 2.405307 & -1.461360 & 3.154965 & -5.151778 \\
\hline $\mathrm{Wt} \% \mathrm{Al}_{2} \mathrm{O}_{3}$ & 9.729227 & -1.244845 & 0.328612 & 1.276168 & -0.920534 \\
\hline $\mathrm{Wt} \% \mathrm{CaF}_{2}$ & -0.752077 & -1.929834 & -0.014758 & -2.036530 & 2.429097 \\
\hline \multicolumn{6}{|c|}{ Threshold for MIDDLE layer } \\
\hline No. 1 & No. 2 & & & No. 4 & No. 5 \\
\hline-0.479840 & 1.710636 & & 556 & -0.387418 & 1.437762 \\
\hline \multicolumn{6}{|c|}{ Weight vector of MIDDLE to OUTPUT layer } \\
\hline No. 1 & No. 2 & & & No. 4 & No. 5 \\
\hline-6.361718 & 2.426691 & & 255 & 2.552417 & -4.141397 \\
\hline \multicolumn{6}{|c|}{ Threshold for OUTPUT layer } \\
\hline \multicolumn{6}{|c|}{-2.059992} \\
\hline
\end{tabular}


ber of middle unit is selected as 5 , the parameters needed are 15 of connection weight matrix of input to middle layer $\left(\mathrm{W}_{\mathrm{ki}}\right), 5$ of threshold parameters of middle layer (critical value) $\left(\mathrm{h}_{\mathrm{i}}\right), 5$ connection weight vector of middle to output layer $\left(\mathrm{V}_{\mathrm{k}}\right)$ and 1 of threshold for output layer $\left(\mathrm{h}_{\mathrm{k}}\right)$, i.e. total 26 parameters. The values of those parameters change sensitively with the number of input data, the number of iteration for learning and so on. As one example, the parameter values for the calculation of $\mathrm{CaO}-\mathrm{CaF}_{2}-\mathrm{Al}_{2} \mathrm{O}_{3}$ slag system at $1773 \mathrm{~K}$ (Fig. 11) are tabulated in Table 3.

Experimental phosphate capacity data of molten state $\mathrm{CaO}-\mathrm{CaF}_{2}-\mathrm{Al}_{2} \mathrm{O}_{3}, \mathrm{CaO}-\mathrm{CaF}_{2}$ and $\mathrm{CaO}-\mathrm{Al}_{2} \mathrm{O}_{3}$ melts at $1773 \mathrm{~K}$ were used as teaching value in order to evaluate isophosphate capacity counters on the ternary phase diagram. As seen in the figure, logarithmic scaled phosphate capacity contours are in good agreement with experimental data and vary between 20.6 and 21.8 .

Derin et al. ${ }^{1)}$ first proposed sulphide capacity model using an artificial neural network concept that was considered as a pioneering study that demonstrates a successful application of the neural network model for impurity capacity prediction of some slag systems. In this study, for phosphate, phosphide, nitride and carbide capacities, a good regression between multicomponent melts and their subsystems was successfully made. Moreover, we believe that a matrix which consists of components, temperature and physical properties such as impurity capacity, viscosity, surface tension, etc. can be calculated with the neural network model at once to estimate their inter-correlations, if enough number of required data is provided.

\section{Conclusions}

In the present work, we applied the artificial neural network calculations to the phosphorus, nitride and carbide capacities predictions in binary and multi-component melts at different temperatures. The NN computation results were found in good agreement with the experimental values. The results showed that the values obtained by neural network computation have lower RMSE values and higher estimation precision than corresponding statistical and thermodynamic models. It was also constructed iso-phosphate counters on ternary phase diagrams of $\mathrm{CaO}-\mathrm{CaF}_{2}-\mathrm{Al}_{2} \mathrm{O}_{3}$ slag system at $1773 \mathrm{~K}$, establishing a link among experimental $C_{P_{4}^{3-}}$ values of molten ternary and lower sub-systems. It can be concluded that artificial neural network based computation is a very useful technique for predicting impurity capacity values in molten melts, when other empirical/theoretical models are not inadequate for their $\mathrm{Ci}$ estimations. But attention needs to be paid to the quantity and accuracy of the experimental data.

\section{REFERENCES}

1) B. Derin, M. Suzuki and T. Tanaka: ISIJ Int., 50 (2010), 1059.

2) R. Selin, Y. Dong and Q. Wu: Scand. J. Metall., 19 (1990), No. 3, 98.

3) Y. Kobayashi, N. Yoshida and K. Nagai: ISIJ Int., 44 (2004), 21

4) T. Mori: Bull. Jpn. Inst. Met., 23 (1984), No. 4, 354.

5) Y. Kobayashi and S. Komada: ISIJ Int., 52 (2012), 960.

6) X. M. Yang, C. B. Shi, M. Zhang, J. P. Duan and J. Zhang: Metall. Trans. B, 42B (2011), 951.

7) B. Maramba and R. H. Eric: Miner. Eng., 21 (2008), 132.

8) M. Sasabe, S. Yamashita, S. Shiomi, T. Tamura, H. Hosokawa and K. Sano: Tetsu-to-Hagané, 87 (2001), 727.

9) W. Y. Shin and H. G. Lee: ISIJ Int., 41 (2001), 239.

10) J. H. Park and D. J. Min: ISIJ Int., 44 (2004), 223.

11) K. Gurney: An Introduction to Neural Network, UCL Press Limited, London, (1997), 2.

12) J. A. Freeman and D. M. Skapura: Neural Networks Algorithms, Applications and Programming Techniques, Addison-Wesley Publishing Company, Reading, MA, (1991), 1, 89.

13) K. Tanabe: An Introduction of Neural Network by Neurosim/L, The Nikkan Kogyo Shinbun, Ltd., Tokyo, (2003), 75.

14) T. Tanaka, M. Nakamoto, M. Kawamoto and M. Hanao: CAMP-ISIJ, 18 (2005), 898.

15) M. Hanao, M. Kawamoto, T. Tanaka and M. Nakamoto: ISIJ Int., 46 (2006), 346.

16) M. Nakamoto, M. Hanao, T. Tanaka, M. Kawamoto, L. Holappa and M. Hamalainen: ISIJ Int., 47 (2007), 1075.

17) Thermfact and GTT-Technologies: FactSage 6.4 Thermochemical Software for WindowsTM, Thermfact/CRCT and GTT-Technologies, Montreal, Canada/Aachen, Germany, (2014).

18) S. Nakamura, F. Tsukihashi and N. Sano: ISIJ Int., 33 (1993), 53.

19) K. Sekino and N. Sano: Tetsu-to-Hagané, 73 (1987), 988.

20) J. Im, K. Morita and N. Sano: ISIJ Int., 36 (1996), 517.

21) W. H. Van Niekerk and R. J. Dippenaar: Metall. Trans. B, 29B (1988), 147.

22) T. Hamano and F. Tsukihashi: ISIJ Int., 45 (2005), 159.

23) G. Li, T. Hamano and F. Tsukihashi: ISIJ Int., 45 (2005), 12

24) Z. H. Tian, B. H. Li, X. M. Zhang and Z. H. Jiang: J Iron Steel Res Int., 16 (2009), No. 3, 6.

25) C. Nassaralla and R. J. Fruehan: Metall. Trans. B, 23B (1992), 117.

26) X. Liu, O. Wijk, R. Selin and J. O. Edström: ISIJ Int., 38 (1998), 36.

27) O. I. Ostrovski, Y. I. Utochkin, A. V. Pavlov and R. A. Akberdin: ISIJ Int., 34 (1994), 849.

28) R. Inoue, H. Suito and M. Ohtani: Bull. Res. Inst. Miner. Dressin. Metall., 40 (1984), 199.

29) F. Tsukihashi, M. Nakamura, T. Orimoto and N. Sano: Tetsu-toHagané, 76 (1990), No. 10, 1664.

30) K. Ito and N. Sano: Tetsu-to-Hagané, 69 (1983), 1747.

31) H. Kimura and F. Tsukihashi: Tetsu-to-Hagané, 83 (1997), 689.

32) T. Kawahara, K. Yamagata and N. Sano: Steel Res., 54 (1986), 160.

33) K. Tomioka and H. Suito: ISIJ Int., 31 (1991), 1316.

34) H. Sakai and H. Suito: ISIJ Int., 36 (1996), 143.

35) J. H. Park, D. J. Min and H. S. Song: ISIJ Int., 42 (2002), 127.

36) J. H. Park, G. H. Park and Y. E. Lee: ISIJ Int., 50 (2010), 1078. 